\title{
15. PETROLOGY AND GEOCHEMISTRY OF DSDP LEG 35 BASALTS, BELLINGSHAUSEN SEA
}

\author{
Walt Vennum, Department of Geology, Sonoma State College, Rohnert Park, California
}

\begin{abstract}
Basaltic rocks were recovered from two sites on the abyssal plain of the Bellingshausen Sea during Leg 35 of the Deep Sea Drilling Project. Disoriented basaltic cobbles, some of which have glassy rinds, hyaloclastite fragments, and numerous chips of black glass cored at Site 322 are interpreted to be the upper surface of a brecciated pillow flow. However, high penetration rates $(12-13 \mathrm{~m} / \mathrm{hr})$ indicate the drilled interval may consist of interbedded lava flows and sediments, and true oceanic basement (layer 2) probably was not reached. Except for an abnormally high $\mathrm{K}_{2} \mathrm{O}$ content, the mineralogy and chemistry are typical of average mid-ocean ridge tholeiites. Many of the plagioclase microphenocrysts contain irregular to sharply bounded cores of almost pure potassium feldspar, a feature previously reported from Sites 165 (Leg 17) and 192 (Leg 19). This feature probably results from the filling of hollow centers of hopper crystals by potassic-rich solutions produced during alteration.

Textural variation, mineralogy, and drilling rates suggest that one and possibly two sills were penetrated at Site 323 , and oceanic basement (layer 2) was not reached. The mineralogy and chemistry are also typical of average mid-ocean ridge basalt although the $\mathrm{K}_{2} \mathrm{O}$ content is abnormally high. The high oxidation index and abnormally low $\mathrm{K}-\mathrm{Ar}$ age suggest that the apparent alkalinity of these rocks has been increased during alteration. A possible sill with even stronger alkaline tendencies has been cored at Site 170 (Leg 17) in the central Pacific, and the occurrence of sills with alkaline affinities in deep oceanic basins indicates the oceanic crust may be far more "leaky" than was originally assumed.
\end{abstract}

\section{INTRODUCTION}

\section{Location}

Basaltic rocks were recovered from two sites on the deep oceanic part of the Antarctic plate during Leg 35 (Figure 1). Site 322 was drilled into a northwestsoutheast-trending fracture zone near the eastern end of the Bellingshausen Abyssal Plain. Site 323 was also situated on the Bellingshausen Abyssal Plain a few miles north of the base of the Antarctic Continental Rise and just south of the Eltanin Fracture Zone. Water depths at both sites exceeded 5000 meters. Prior seismic profiles through these sites (Eltanin 43 and Eltanin 42, respectively) indicated a rough to moderately rough basement overlain by less than a kilometer of sediment.

\section{Mode of Emplacement}

Unambiguous conclusions regarding the mode of emplacement of the basalt cannot be made for either site. About 30 cobbles of very fine-grained basalt, several cobbles of basaltic breccia, and numerous small fragments of black glass were recovered at Site 322 . Gradational changes from glassy rinds through variolitic zones to fine-grained diabasic basalt are present in many basaltic cobbles and are typical of the textural changes found in pillow flows recovered on other DSDP legs. The breccia cobbles contain fragments of variolitic and diabasic basalt, but consist mostly of angular fragments of glass and palagonite embedded in a glassy matrix. This assemblage is probably the upper surface of a brecciated pillow basalt flow. However, it is not clear that this material represents true igneous basement (layer 2). The presence of innumerable sedimentary fragments incorporated with the basaltic cobbles suggests that the drilled interval may consist of interbedded thin lava flows and sediments. At Site 332A (Leg 37) a 333-meter-thick section of basalt and interbedded foram-bearing nanno ooze was penetrated adjacent to the Mid-Atlantic Ridge, demonstrating that sedimentary zones may be abundant below acoustic basement. The basalt-sediment contact was not recovered at Site 322, but overlying brown claystone and the included sedimentary fragments do not show the effects of contact metamorphism. The sedimentary fragments mixed with the basalt may have been derived from interbedded sediments or may have been washed downhole during the drilling process.

Textural variations, mineralogy, and drilling rates suggest that one and possibly two sills were penetrated at Site 323 and oceanic basement was not reached. The basalt-sediment contact was poorly preserved and no evidence of baking was found, although Garrison et al. (1973) have shown that the contact effects produced by intrusive submarine basalts may be very small or nonexistent. An essentially unbroken 7-meter section from the top of the drilled interval possesses both upper and 


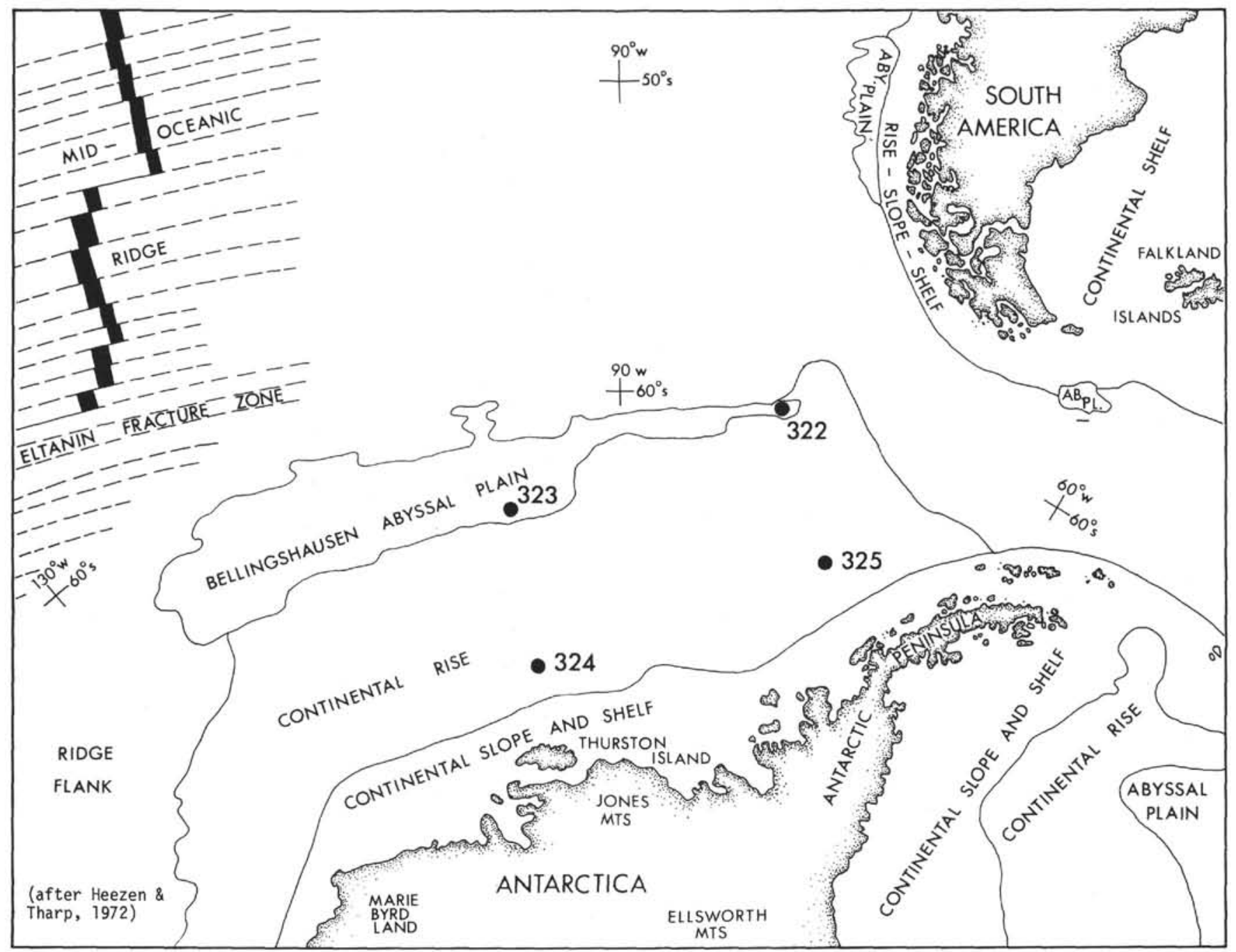

Figure 1. Site location of DSDP Leg 35 holes in relation to topographic features on the floor of the Bellinghausen Sea.

lower chilled margins containing varioles of plagioclase and pyroxene quench crystals. These chilled margins grade inward to subophitic and ophitic basalt. Olivine is virtually restricted to the lower variolitic zone where its presence may be attributed to crystal settling. Core recovery was poor below this level and no sediment was recovered, but increased drilling rates suggest that softer material was penetrated. The low hummocky relief of acoustic basement and the evidence for considerable fractionation (Table 1) also suggest origin as a sill.

\section{Analytical Methods}

Wet method chemical analyses were determined at the Smithsonian Institution by Julie J. Norberg. Rock densities were determined onboard ship using a gamma ray attenuation porosity evaluator (GRAPE), and $\mathrm{CO}_{2}$ values were determined by high-temperature gas chromatography. Preliminary electron microprobe analyses of pyroxene and feldspar were performed at Stanford University and NASA Ames Research Center, Moffit Field, California, respectively. Whole rock K-Ar dates (Table 2) were determined by David Seidemann at Yale University. Sonic velocities were determined by N.I. Christensen and are reported elsewhere in this volume. Plagioclase compositions were determined from extinction angles measured to albite and Carlsbad-albite twin lamellae in the zone perpendicular to the side pinacoid or on sections normal to the base and side pinacoids and were checked with refractive index oils. Refractive indices of plagioclase and basaltic glass were determined with standard oil immersion techniques utilizing a sodium light source. Modes were determined for two analyzed samples by counting approximately 800 points following the methods of Van der Plas and Tobi (1965). Chemical analyses, CIPW norms, and modes of analyzed samples are listed in Tables 1, 3, and 4.

Terms used in this paper are defined as follows: oxidation index $=100 \mathrm{Fe}_{2} \mathrm{O}_{3} /\left(\mathrm{FeO}+\mathrm{Fe}_{2} \mathrm{O}_{3}\right)$; differentiation index (Thornton and Tuttle, 1960) = sum of the weight percent of normative quartz, orthoclase, albite, nepheline, leucite, and kalsilite; solidification index (Kuno, $1962=\left(\mathrm{MgO} / \mathrm{MgO}+\mathrm{FeO}+\mathrm{Fe}_{2} \mathrm{O}_{3}+\mathrm{Na}_{2} \mathrm{O}\right.$ $\left.+\mathrm{K}_{2} \mathrm{O}\right)(100)$.

\section{Alteration}

DSDP Leg 35 basalts average $1 \% \mathrm{H}_{2} \mathrm{O}^{+}$, but far exceed published values of $\mathrm{Fe}_{2} \mathrm{O}_{3}$ and $\mathrm{H}_{2} \mathrm{O}^{-}$for unaltered 
TABLE 1

Chemical Analyses ${ }^{\mathrm{a}}$

\begin{tabular}{lcc}
\hline $\begin{array}{l}\text { Weight } \\
\text { Percent } \\
\text { Oxides }\end{array}$ & $\begin{array}{c}\text { Sample } \\
35-322-12-1, \\
101-105 \mathrm{~cm}\end{array}$ & $\begin{array}{c}\text { Sample } \\
35-323-19-4 \\
14-16 \mathrm{~cm}\end{array}$ \\
\hline $\mathrm{SiO}_{2}$ & 48.97 & 48.20 \\
$\mathrm{Al}_{2} \mathrm{O}_{3}$ & 16.14 & 13.77 \\
$\mathrm{Fe}_{2} \mathrm{O}_{3}$ & 5.00 & 6.12 \\
$\mathrm{FeO}$ & 3.88 & 5.95 \\
$\mathrm{MgO}$ & 6.14 & 5.81 \\
$\mathrm{CaO}$ & 11.71 & 10.43 \\
$\mathrm{Na}_{2} \mathrm{O}$ & 2.54 & 2.62 \\
$\mathrm{~K}_{2} \mathrm{O}$ & 0.81 & 0.53 \\
$\mathrm{H}_{2} \mathrm{O}^{+}$ & 0.93 & 1.03 \\
$\mathrm{H}_{2} \mathrm{O}^{-}$ & 2.28 & 2.67 \\
$\mathrm{TiO}_{2}$ & 1.54 & 2.89 \\
$\mathrm{P}_{2} \mathrm{O}_{5}$ & 0.20 & 0.23 \\
$\mathrm{MnO}$ & 0.14 & 0.23 \\
$\mathrm{CO}_{2}$ & $0.04^{\mathrm{b}}$ & $0.08^{\mathrm{b}}$ \\
Total & 100.32 & 100.57 \\
O.I. $^{\mathrm{c}}$ & 56.3 & 50.7 \\
$\mathrm{S.I}^{\mathrm{C}}$ & 33.4 & 27.6 \\
D.I. $^{\mathrm{c}}$ & 29.7 & 31.6 \\
Density $^{\mathrm{C}}$ & $2.72^{\mathrm{d}}$ & $2.72^{\mathrm{d}}$ \\
\hline
\end{tabular}

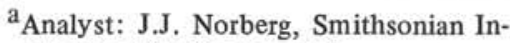
stitution, Washington, D.C.

${ }^{b}$ Average of three determinations by high-temperature gas chromatograph.

cSee text.

${ }^{\mathrm{d}}$ Value determined onboard ship by GRAPE in g/cc.

abyssal tholeiite (Miyashiro et al., 1969); see Table 1. Oxidation indexes for both samples exceed $50 . \mathrm{K}_{2} \mathrm{O}$ values for both sites (Table 1) are considerably above the average for mid-ocean ridge basalt (Engel, et al., 1965). Ford (1975) has shown that $\mathrm{K}_{2} \mathrm{O}$ increases with oxidation in Leg 28 basalts. The high oxidation indexes and anomalously low K-Ar dates (Table 2) indicate that alteration has increased the apparent alkalinity of basalt recovered at both Leg 35 sites. Ford (1975) reported olivine tholeiite glass with $0.47 \% \mathrm{~K}_{2} \mathrm{O}$ from Leg 28 , Site 266 , and in the absence of visible alteration concluded that the $\mathrm{K}_{2} \mathrm{O}$ value was primary; however, this sample had an oxidation index of only 17 . Average $\mathrm{CO}_{2}$ values
(Table 1) are indicative of fresh basalt, but the samples were deliberately selected to avoid visible calcite veins. Bass et al. (1973) and Thompson (1973) have both emphasized the caution necessary in determining original magmatic composition from chemical analyses showing evidence of extensive alteration. Salisbury and Christensen (1973) demonstrated that halmyrolysis may affect submarine basalt buried beneath as much as several hundred meters of marine sediments.

CIPW normative calculations are strongly affected by extensive oxidation of iron. Norms (Table 3) consequently have been calculated from the original analyses, and from the original analyses calculated volatile-free and with excess $\mathrm{Fe}_{2} \mathrm{O}_{3}$ (over $1.5 \%$ ) recalculated as $\mathrm{FeO}$. This recalculation assumes that all $\mathrm{Fe}_{2} \mathrm{O}_{3}$ in excess of $1.5 \%$ is due to secondary alteration (Coombs, 1963; Shido et al., 1971).

\section{SITE 322}

\section{Site Description}

Site 322 was drilled in 5026 meters of water at $60^{\circ} 01.45^{\prime} \mathrm{S}, 79^{\circ} 25.49^{\prime} \mathrm{W}$ on the eastern edge of the Bellingshausen Abyssal Plain. Basalt was first recovered at a subbottom depth of 514.0 meters and was cored continuously for 30 meters. Recovery averaged $17 \%$ for Cores 12 and 13, but Core 14 was barren. Additional cobbles were collected from the core catcher from Core 11.

\section{Crustal Age}

Three models can be proposed for the age of the crust at this site. Extrapolation of known magnetic anomalies which parallel the East Pacific Rise (Pitman et al., 1968) suggests a Mesozoic age, probably Early Cretaceous. If Herron's (1971) interpretation of the Chile Ridge as a spreading axis is correct, then ocean crust spreading southwestward from this center to the vicinity of Site 322 should be early Tertiary. Griffiths and Barker (1972) have described a northeast-trending spreading axis in the Drake Passage. Crustal material originating at this center would be late Cenozoic in age in the vicinity of Site 322. Pelagic brown clay recovered from just above the basalt is early Miocene to (?) Oligocene in age (see Site 322 paleontology report this volume), but the basement age is uncertain.

Several interpretations are possible: (1) the basalts are middle Tertiary and represent a random sea-floor erup-

TABLE 2

Whole Rock K-Ar Isotopic Ages ${ }^{\mathrm{a}}$

\begin{tabular}{|c|c|c|c|c|c|c|}
\hline Hole & Core & Section & Piece & $\% \mathrm{~K}$ & $\begin{array}{l}\text { Radiogenic } \mathrm{Ar}^{40} \\
\times 10^{-6} \text { cc STP }\end{array}$ & Date (m.y.) \\
\hline 322 & 12 & 1 & 8 & $0.86 \pm 0.02$ & $\begin{array}{l}0.38 \pm 0.03 \\
0.52 \pm 0.18 \\
0.35 \pm 0.12\end{array}$ & $\begin{array}{l}11.1 \pm 1.2 \\
15.1 \pm 3.8 \\
10.2 \pm 3.6\end{array}$ \\
\hline 322 & 12 & 1 & 9 & $0.67 \pm 0.02$ & $\begin{array}{l}0.27 \pm 0.09 \\
0.27 \pm 0.01\end{array}$ & $\begin{array}{l}10.2 \pm 3.6 \\
10.2 \pm 0.8\end{array}$ \\
\hline 323 & 21 & $\mathrm{CC}$ & - & $0.74 \pm 0.02$ & $\begin{array}{l}1.38 \pm 0.03 \\
1.40 \pm 0.03\end{array}$ & $\begin{array}{l}46.2 \pm 2.4 \\
47.0 \pm 2.4\end{array}$ \\
\hline
\end{tabular}

${ }^{a}$ Analyst: D. Seidemann, Yale University. 
TABLE 3

CIPW Norms

\begin{tabular}{|c|c|c|c|c|}
\hline & \multicolumn{2}{|c|}{ Site 322} & \multicolumn{2}{|c|}{ Site 323} \\
\hline & A & B & A & B \\
\hline Q & 2.9 & - & 5.7 & 0.3 \\
\hline OR & 4.9 & 4.9 & 3.2 & 3.3 \\
\hline $\mathrm{Ab}$ & 21.9 & 22.2 & 22.6 & 23.0 \\
\hline An & 30.6 & 31.3 & 24.8 & 25.2 \\
\hline Wo & 11.2 & 11.5 & 10.9 & 11.3 \\
\hline En & 15.6 & 13.2 & 14.8 & 15.0 \\
\hline Fs & 0.7 & 8.1 & 1.6 & 13.5 \\
\hline Fo & - & 1.9 & - & - \\
\hline $\mathrm{Fa}$ & - & 1.3 & - & - \\
\hline Mt & 7.4 & 2.2 & 9.1 & 2.3 \\
\hline II & 3.0 & 3.0 & 5.6 & 5.7 \\
\hline Ap & 0.5 & 0.5 & 0.6 & 0.6 \\
\hline CC & 0.1 & - & 0.2 & - \\
\hline Total & 98.8 & 100.1 & 99.1 & 100.2 \\
\hline Salic & 60.6 & 58.4 & 56.3 & 51.7 \\
\hline Femic & 38.5 & 41.6 & 42.6 & 48.3 \\
\hline DI & 21.0 & 22.4 & 20.5 & 22.2 \\
\hline DI-Wo & 11.2 & 11.5 & 10.9 & 11.2 \\
\hline DI-En & 9.4 & 6.8 & 8.7 & 5.8 \\
\hline DI-Fs & 0.4 & 4.1 & 0.9 & 5.2 \\
\hline $\mathrm{Hy}$ & 6.5 & 10.3 & 6.7 & 17.5 \\
\hline Hy-En & 6.2 & 6.4 & 6.1 & 9.2 \\
\hline $\mathrm{Hy}-\mathrm{Fs}$ & 0.3 & 3.9 & 0.6 & 8.3 \\
\hline $\mathrm{Ol}$ & - & 3.2 & - & - \\
\hline Ol-Fo & - & 1.9 & - & - \\
\hline $\mathrm{Ol}-\mathrm{Fa}$ & - & 1.3 & - & - \\
\hline D. I. & 29.7 & 27.2 & 31.6 & 26.6 \\
\hline
\end{tabular}

Note: $\mathrm{A}=$ original analysis $\mathrm{B}=$ volatile free with excess $\mathrm{Fe}_{2} \mathrm{O}_{3}$ calculated as $\mathrm{FeO}$.

\begin{tabular}{|c|c|c|}
\hline & $\begin{array}{c}\text { Sample } \\
35-322-12-1, \\
101-105 \mathrm{~cm}\end{array}$ & $\begin{array}{c}\text { Sample } \\
35-323-19-4, \\
14-16 \mathrm{~cm}\end{array}$ \\
\hline Plagioclase & 43.6 & 46.1 \\
\hline Clinopyroxene & 36.1 & 40.3 \\
\hline Opaque oxides & 4.8 & 3.1 \\
\hline Olivine & $\operatorname{tr}$ & $\operatorname{tr}$ \\
\hline Carbonate & - & 0.2 \\
\hline $\begin{array}{l}\text { Matrix (microlites and } \\
\text { very fine-grained } \\
\text { alteration products) }\end{array}$ & 14.8 & 8.6 \\
\hline Vesicles and amygdules & 0.7 & 1.7 \\
\hline
\end{tabular}

tion; (2) the basalts are middle Tertiary in age and may represent true igneous basement; (3) the basalts represent true basement and may be as old as Cretaceous; the lack of pre-middle Tertiary sediments overlying the basalt being due to erosion by bottom currents which diminished by the Miocene. The presence of fresh glass suggests a Cenozoic age, but several factors support the basement interpretation: (1) lithologic and chemical similarity to other DSDP basalts interpreted to be true basement; (2) absence of deeper reflectors on seismic profiles of the area; (3) lateral continuity of acoustical basement beneath most of the abyssal plain. The problem of finding a nearby spreading axis source for a middle Tertiary basement is still unsolved. $\mathrm{K}-\mathrm{Ar}$ dates (Table 2) obtained from Site 322 are geologically unrealistic.

\section{Petrography}

Individual cobbles from Site 322 are too small to show the complete gradation from glassy rind to holocrystalline basalt, but collectively they exhibit the complete range of textures and mineralogy found in pillow basalts recovered on DSDP Leg 16 (Yeats et al., 1973) and from Eltanin dredge samples (Paster, 1971). Rims of clear light brown glass (R.I. $=1.565 \pm 0.002$ ) containing small plagioclase laths $(0.1-0.25 \mathrm{~mm})$ are veined by pale to deep yellow palagonite $($ R.I. $=1.525$ \pm 0.002 ). Inward from the cobble margins the glass grades sharply into an opaque dark brown to dark redbrown zone composed almost entirely of polygonal globules $(0.05-0.10 \mathrm{~mm})$ consisting of radially arranged microlites. These globules become so closely packed that their polygonal shape is often partially distorted. Preliminary microprobe analysis indicates that the microlites are plagioclase and clinopyroxene, but their small size precluded precise compositional determination. Fan-shaped or plumose varioles of clinopyroxene appear interior to the globular zone. These varioles have not nucleated around the plagioclase, but many of the feldspar laths have indistinct edges caused by the growth of incipient pyroxene microlites perpendicular to their margins. Minute grains of magnetite are concentrated along the margins of the plumose varioles, but this mineral does not occur in the outer globular zone or in the glassy margins. Scattered amygdules occur only in this variolitic zone and are filled with nonpleochroic light green smectite.

The varioles grade into very fine-grained diabasic basalt. Rare euhedral olivine microphenocrysts occur in these innermost zones and are completely pseudomorphed by iddingsite and in places veined by serpentine. Widely scattered glomeroporphyritic clots of plagioclase and pyroxene occur throughout the diabasic basalt. Cores of the larger clinopyroxene grains are augite $\left(\mathrm{Ca}_{43} \mathrm{Mg}_{30} \mathrm{Fe}_{27}\right)$ which grades outward to ferroaugite $\left(\mathrm{Ca}_{40} \mathrm{Mg}_{24} \mathrm{Fe}_{36}\right)$. Smaller groundmass grains are somewhat variable in composition, but generally fall within the above limits. Titanium content averages between $0.50 \%$ and $0.75 \%$.

Plagioclase within the variolitic and diabasic zones occurs as acicular needles or as rectangular microphenocrysts. The needles have length to width ratios as high as 20 or $30: 1$, are commonly doubly swallow-tailed, and are twinned on both the albite and Carlsbad laws. Zonation is weak or absent and composition ranges only from cores of $A_{70}$ to rims of Ano5. The larger needles are isolated in the groundmass, but the smaller ones are arranged in fan-shaped aggregates or grow from a common center like the spokes of a wheel. None of the needles or microphenocrysts are sausseritized, but $25 \%$ of each are hollow hopper crystals cored with intergrown clinopyroxene needles and opaque grains. Interstitial potassium feldspar $(5 \mu \mathrm{m})$ or potassic-rich glass of variable composition was detected in both the 
groundmass and the filled centers of the hopper crystals. The microphenocrysts are essentially untwinned and only occasionally show slight oscillatory zoning. Their refractive indexes are similar to that of the needles. Approximately $40 \%$ of the plagioclase needles and microphenocrysts contain sharp to irregularly bounded cores of nearly pure ( $98 \%-99 \%)$ potassium feldspar, only minor amounts of $\mathrm{Na}_{2} \mathrm{O}$ and $\mathrm{CaO}$ being detected with the microprobe.

\section{Chemistry}

The rare occurrence of olivine phenocrysts, the absence of groundmass olivine, the pyroxene compositions, and the late crystallization of magnetite are suggestive of a tholeiitic composition. Chemically, basalt from Site 322 is a tholeiite, and except for its high $\mathrm{K}_{2} \mathrm{O}$ content compares favorably with average midocean ridge basalts (Engel et al., 1965). On a total alkalisilica diagram (Figure 2) it plots near the boundary between alkalic basalt and tholeiite. Bass et al. (1973) have shown that weathering of submarine basalt commonly results in an increase in apparent alkalinity, and total alkali-silica diagrams are thus somewhat misleading in terms of judging original magmatic composition. Bass et al. (1973) have also shown that certain refractory minor or trace elements retain their original or relative concentrations even in relatively highly altered rocks. Plots of $\mathrm{TiO}_{2}$ versus $\mathrm{P}_{2} \mathrm{O}_{5}$ are particularly valuable in relation to submarine basalts, and on such a graph (Figure 3) Site 322 basalt plots well inside the field of ocean ridge basalts. Norms calculated from the original analysis contain quartz and hypersthene, but quartz is replaced by normative olivine if the calculations are performed on a volatile-free basis with excess $\mathrm{Fe}_{2} \mathrm{O}_{3}$ calculated as $\mathrm{FeO}$. Hypersthene and olivine normative basalts are classified as undersaturated olivine tholeiites by Yoder and Tilley (1962).

Replacement of calcic cores of zoned plagioclase by potassium feldspar has been reported by Bass et al. (1973) from tholeiitic basalts recovered at Site 165 on DSDP Leg 17 in the central Pacific and by Stewart et al. (1973) from alkalic basalts recovered at Site 192 on DSDP Leg 19 in the north Pacific. It is difficult to explain the sharp rectangular boundary between some of the potassium feldspar cores and the sodic rims by other than magmatic crystallization, but in many cases the core-rim boundaries are highly irregular and thus are indicative of replacement processes. Carmichael (1963) has shown that magma containing appreciable $\mathrm{CaO}$ would crystallize pure anorthite along with pure

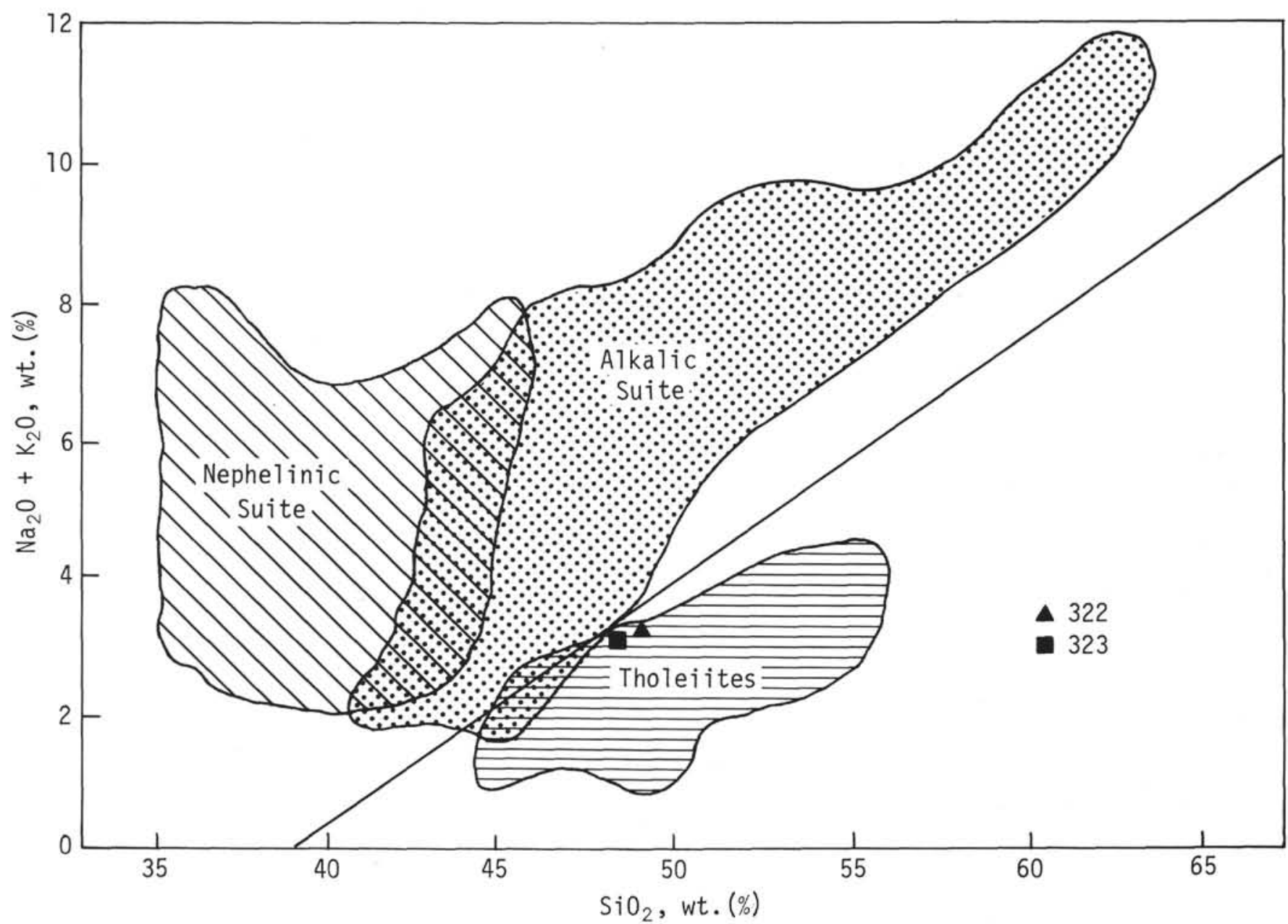

Figure 2. Composition of DSDP Leg 35 basalts in relation to total alkalies versus silica. Fields of various basalt types from MacDonald (1963). 


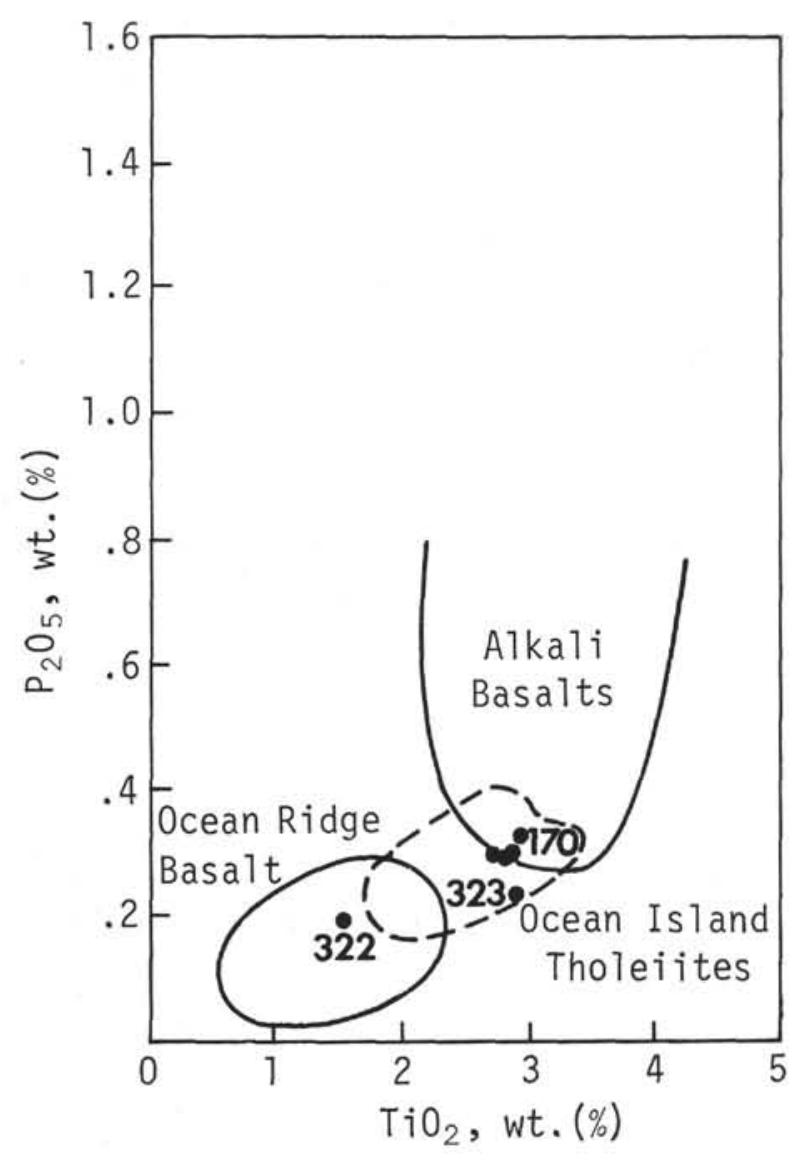

Figure 3. Composition of DSDP Leg 35 basalts in relation to weight $\% \mathrm{TiO}_{2}$ versus weight $\% \mathrm{P}_{2} \mathrm{O}_{5}$. The four analyses from Site 170 are from a sill (?) cored on Leg 17 in the Central Pacific. Fields of the various basalt types from Bass and others (1973).

orthoclase at pressures up to $10 \mathrm{kbar}$ or that magmatic orthoclase coexisting with calcic labradorite should contain $10 \%-20 \%$ of the albite molecule. Carmichael (1963) has also concluded that only a single feldspar, plagioclase, will crystallize from a differentiating basaltic magma uncontaminated by continental crust. A magmatic origin for the $\mathrm{K}$-feldspar cores thus appears impossible. Lack of $\mathrm{K}$-feldspar xenocrysts in the groundmass and glassy rinds negates a xenocrystic origin for the cores. Bass et al. (1973) and Stewart et al. (1973) concluded that the potassic cores originated through replacement processes. It is unusual, however, that potassic-rich fluids would replace only the original calcic cores and not affect the outer more sodic portions of the grains. A thin rim $(0.10 \mathrm{~mm})$ showing a slightly different extinction position often appears on the outer margin of the otherwise unzoned sodic portions of these grains. The composition of these rims was, however, unfortunately not checked with the microprobe.

Petrographic features associated with Site 322 basalt suggest another possible origin. Intergrown masses of clinopyroxene, opaques, and interstitial K-feldspar which infill plagioclase hopper crystals have overall compositions similar to the groundmass. This feature has been reported from previous DSDP basalts (Bryan,
1972; Yeats et al., 1973) and suggests that the K-feldspar cores are fillings of initially hollow crystals by fluids produced during alteration. This process would in most cases preserve a sharp core-rim boundary, but could also replace the interior margins of the sodic rims in some instances.

\section{SITE 323}

\section{Site Description}

Site 323 was drilled in 5003 meters of water at $63^{\circ} 40.84^{\prime} \mathrm{S}, 97^{\circ} 59.69^{\prime} \mathrm{W}$ on the Bellingshausen Abyssal Plain a few miles north of the base of the Antarctic Continental Rise. Basalt was first recovered at a subbottom depth of 701.0 meters and was cored continuously for 30 meters. Recovery averaged $45 \%$ for Cores 19 and 20, but only a few fragments were recovered in the core catcher from Core 21 . Approximately $150 \mathrm{~cm}$ was recovered from the base of Core 18 .

\section{Crustal Age}

The oldest overlying sediments at Site 323 are zeolitic brown claystones of Maestrichtian age (70 m.y.). The basalt correlates with the deepest observed seismic reflector (DOR), but petrographic evidence suggests that a sill was penetrated and that layer 2 was not reached. The Late Cretaceous age from nannoplankton in the overlying sediments (see Site 323 paleontology report, this volume) indicates that true basement lying below the DOR is at least 70 m.y. old and close to the 81 m.y. age suggested by the nearest magnetic anomaly (33?). K-Ar dates (Table 2) obtained from this site are anomalously low.

\section{Petrography}

The basalt from Site 323 is dark gray (N3), aphanitic to extremely fine-grained, and essentially aphyric although a very few scattered microphenocrysts of plagioclase and pseudomorphic olivine do occur. Most cores are moderately to extensively veined with calcite, and fracture surfaces are coated with smectite and reddish-brown iron oxides. Smectite-filled amygdules $(0.5 \mathrm{~mm})$ are nowhere numerous, but occur scattered throughout most of the core. No glassy zones were found in the cores, nor was any brecciated basalt or hyaloclastite material recovered.

Microscopic examination of an essentially unbroken 7-meter section from the top of the drilled interval revealed a series of gradational textural changes which may be quite diagnostic of mode of occurrence. The uppermost basalt has an intergranular-intersertal texture. The intersertal matrix contains varioles of plagioclase and minute pyroxene quench crystals. This variolitic zone grades downward through intergranular and pilotaxitic basalt to subophitic and ophitic basalt which make up most of this 7-meter interval. Variolitic plagioclase and pyroxene quench crystals reappear in the basalt recovered from lower cores. This range of textures suggests that a sill was drilled. The virtual restriction of olivine to the lower variolitic zone can be attributed to gravitational settling also within a sill. Variolitic textures are usually found in pillow margins, 
but have been reported from sills (Wilson, 1960; Garrison, 1972). Pilotaxitic texture is a feature usually found in andesites and is uncommon in more mafic volcanics, although it has been reported from other DSDP basalts (Erlank and Reid, 1974; Thompson et al., 1974).

The origin of the basalt recovered in the core catcher from the lowermost core is purely speculative. This material has an intergranular to subophitic texture, contains scattered plagioclase phenocrysts up to $4 \mathrm{~mm}$ in length, and could have come from the interior of a flow, dike, or sill. The absence of glassy material in the lowermost two cores, and mineralogy and alteration identical to that in the overlying basalt suggest that a second sill was penetrated. Sediment was not recovered in either of the lower two cores, but increased drilling rates suggest that softer material was penetrated.

Subhedral to euhedral labradorite laths (Anss) range in length from 100 to $700 \mu \mathrm{m}$ (average $400 \mu \mathrm{m}$ ), show very little zoning, and are essentially fresh. Plagioclase phenocrysts are blocky, fresh, and very slightly zoned $\left(A_{55-50}\right)$. Most are twinned on the Carlsbad law. These grains average $1.5-2 \mathrm{~mm}$ in longest dimensions except in samples from Core 21 where they attain a size of $4 \mathrm{~mm}$.

Clinopyroxene grains are anhedral, or in only a few cases subhedral, and mainly occur interstitial to the plagioclase. Phenocrysts $(1.5 \mathrm{~mm})$ are uncommon, and these generally occur in small rare glomeroporphyritic clots of 3-5 grains with or without plagioclase. Their average compositions range from calcic augite cores $\left(\mathrm{Ca}_{38} \mathrm{Mg}_{32} \mathrm{Fe}_{30}\right)$ to subcalcic ferroaugite rims $\left(\mathrm{Ca}_{34} \mathrm{Mg}_{26} \mathrm{Fe}_{40}\right)$. Groundmass grains are rather variable in composition, but most are subcalcic ferroaugites with a slightly higher $\mathrm{Mg} / \mathrm{Fe}$ ratio than the phenocryst rims. Many of the plagioclase laths are strongly resorbed where they are in contact with the groundmass pyroxenes.

Euhedral microphenocrysts of olivine $(1.5 \mathrm{~mm})$ comprise $1 \%$ of the lower variolitic zone and also occur in the basalt recovered in Core 21. Those in Core 21 are moderately resorbed. Where present these grains have been completely replaced by calcite that is sometimes rimmed and/or veined by iddingsite and/or serpentine. Euhedral magnetite octahedrons and skeletal rods of ilmenite (?) are confined to the groundmass. Traces of apatite occur in about $30 \%$ of the thin sections.

\section{Chemistry}

The pyroxene compositions, the rarity of olivine phenocrysts, the absence of groundmass olivine, and the resorption of the olivine from Core 21 suggest a tholeiitic composition. Except for a high $\mathrm{K}_{2} \mathrm{O}$ content, this sample compares favorably with average mid-ocean ridge basalts (Engel et al., 1965). The anomalously low $\mathrm{K}-\mathrm{Ar}$ date and high oxidation index suggest that the high potassium content is not a primary feature of the original magma. On a total silica-alkali diagram (Figure 2) this sample plots near the boundary between alkalic basalt and tholeiite. Its alkaline tendencies are better displayed on a $\mathrm{P}_{2} \mathrm{O}_{5}-\mathrm{TiO}_{2}$ diagram (Figure 3 ) where it plots just inside the ocean island tholeiite field. Bass et al. (1973) have described a possible sill from Site 170,
DSDP Leg 17, in the central Pacific that has even stronger alkaline tendencies (Figure 3 ). The occurrence of possible sills with alkaline affinities in deep oceanic basins indicates that the ocean crust may be far more "leaky" than was originally assumed.

The rather high total iron $(12.07 \%)$ and titanium $(2.89 \%)$, the low magnesium content $(5.81 \%)$, and low solidification index (27.6) are indicative that considerable fractionation has taken place. Fractionation may have taken place either within the sill or in a shallow underlying reservoir. Normative computations based on the original analysis and those calculated on a volatile-free basis with excess $\mathrm{Fe}_{2} \mathrm{O}_{3}$ calculated as $\mathrm{FeO}$ both contain normative quartz and hypersthene and lie in the oversaturated tholeiite field in Yoder and Tilley's (1962) normative classification.

\section{ACKNOWLEDGMENTS}

The tedious task of making thin sections, determining preliminary chemical data, sonic velocities, and whole rock densities was performed onboard Glomar Challenger during the cruise by three indispensable marine technicians; Bill Jones, Craig Dootson, and Bob Iuliucci. I am indebted to Ms. Julie Norberg of the Smithsonian institute for the chemical analyses. Dr. Art Ford of the U.S. Geological Survey provided the normative computations and made available his data from the Leg 28 basalts. Drs. Richard Stewart and Ted Bunch reviewed the paper and offered valuable suggestions toward its revision. The manuscript was typed by my wife, Barbara.

\section{REFERENCES}

Bass, M.N., Moberly, R.M., Rhodes, J.M., and Shih, C., 1973. Volcanic rocks cored in the central Pacific, Leg 17, Deep Sea Drilling Project. In Winterer, E.L., Ewing, J.I., et al., Initial Reports of the Deep Sea Drilling Project, Volume 17: Washington (U.S. Government Printing Office), p. 429-504.

Bryan, W.B., 1972. Textural and mineralogical relations of basalt from Sites 100 and 105. In Hollister, C.D., Ewing, J.I., et al., Initial Reports of the Deep Sea Drilling Project, Volume 11: Washington (U.S. Government Printing Office), p. 873-876.

Carmichael, I.S., 1963. The crystallization of feldspar in volcanic acid glass: Geol. Soc. London Quart, J., v. 119, p. 95-131.

Coombs, D.S., 1963. Trends and affinities of basaltic magmas and pyroxenes as illustrated on the diopside-olivine-silica diagram: Min. Soc. Am. Spec. Paper 1, p. 227-250.

Engel, A.E.J., Engel, C.G., and Havens, R.G., 1965. Chemical characteristics of oceanic basalts and the upper mantle: Geol. Soc. Am. Bull., v. 76, p. 719-734.

Erlank, A.J. and Reid, D.L., 1974. Geochemistry, mineralogy and petrology of basalts, Leg 25, Deep Sea Drilling Project. In Simpson, E.S.W., Schlich, R., et al., Initial Reports of the Deep Sea Drilling Project, Volume 25: Washington (U.S. Government Printing Office), p. 543-552.

Ford, A.B., 1975. Antarctic deep-sea basalt, southeast Indian Ocean and Balleny Basin, Deep Sea Drilling Project Leg 28. In Hayes, D.E., Frakes, L.A., et al., Initial Reports of the Deep Sea Drilling Project, Volume 28: Washington (U.S. Government Printing Office), p. 821-834.

Garrison, R.E., 1972. Inter- and intrapillow limestones of the Olympic Peninsula, Washington: J. Geol., v. 80, p. 310-322.

Garrison, R.E., Hein, J.R., and Anderson, T.F., 1973. Lithified carbonate sediment and zeolitic tuff in basalts, Mid-Atlantic Ridge: Sedimentology, v. 20, p. 399-410. 
Griffiths, D.H. and Barker, P.F., 1972. Review of marine geophysical investigations in the Scotia Sea. In Adie, R.J. (Ed.), Antarctic geology and geophysics: Oslo (Universitetsforlaget), p. 3-11.

Herron, E.M., 1971. Crustal plates and sea floor spreading in the southeastern Pacific. In Reid, J.L. (Ed.), Antarctic oceanology I: Am. Geophys. Union, p. 229-237.

Kuno, H., 1962. Frequency distribution of rock types in oceanic, orogenic and kratogenic volcanic associations. In MacDonald, G.A. and Kuno, H. (Eds.), The Crust of the Pacific Basin: Am. Geophys. Union, Geophys. Monogr. 6, p. 133-139.

MacDonald, G.A., 1963. Physical properties of erupting Hawaiian magmas: Geol. Soc. Am. Bull., v. 74, p. 1071-78.

Miyashiro, A., Shido, F., and Ewing, M., 1969. Diversity and origin of abyssal tholeiite from the Mid-Atlantic Ridge near $24^{\circ}$ and $30^{\circ}$ north latitude: Contrib. Min. Petrol., v. 23 , p. $38-52$.

Paster, T.P., 1971. Petrologic variations within submarine basalt pillows of the south Pacific Ocean. In Reid, J.L. (Ed.), Antarctic oceanology I: Am. Geophys. Union, p. 283-308.

Pitman, W.C., Herron, E.M., and Heirtzler, J.R., 1968. Magnetic anomalies in the Pacific and sea floor spreading: J. Geophys. Res., v. 73, p. 2069-2085.

Salisbury, M.H. and Christensen, N.I., 1973. Progressive weathering of submarine basalt with age: further evidence for sea floor spreading: Geology, v. 1, p. 63-64.

Shido, F., Miyashiro, A., and Ewing, M., 1971. Crystallization of abyssal tholeiites: Contrib. Min. Petrol., v. 31, p. 251.

Stewart, R.J., Natland, J.H., and Glassley, W.R., 1973. Petrology of volcanic rocks recovered on Deep Sea Drilling
Project Leg 19 from the north Pacific Ocean and Bering Sea. In Creager, J.S., Scholl, D.W., et al., Initial Reports of the Deep Sea Drilling Project, Volume 19: Washington (U.S. Government Printing Office), p. 615-628.

Thompson, G., 1973. A geochemical study of the lowtemperature interaction of seawater and oceanic igneous rocks: Am. Geophys. Union Trans., v. 54, p. 1015-1019.

Thompson, G., Bryan, W.B., Frey, F.A., and Sung, C.M., 1974. Petrology and geochemistry of basalts and related rocks from Sites 214, 215 and 217, Deep Sea Drilling Project Leg 22 Indian Ocean. In von der Borch, C.C., Sclater, J.G., et al., Initial Reports of the Deep Sea Drilling Project, Volume 22: Washington (U.S. Government Printing Office), p. 459-468.

Thornton, C.P. and Tuttle, O.F., 1960. Chemistry of igneous rocks I. differentiation index: Am. J. Sci., v. 258, p. 664684.

Van der Plas, L. and Tobi, A.C., 1965. A chart for judging the reliability of point counting results: Am. J. Sci., v. 263, p. $87-90$.

Wilson, M.E., 1960. Origin of pillow structure in early Precambrian lavas of western Quebec: J. Geol., v. 68, p. 97 102.

Yeats, R.S., Forbes, W.C., Heath, G.R., and Scheidegger, E.F., 1973. Petrology and geochemistry of Deep Sea Drilling Project Leg 16 basalts, eastern Equatorial Pacific. In van Andel, T.H., Heath, G.R., et al., Initial Reports of the Deep Sea Drilling Project, Volume 16: Washington (U.S. Government Printing Office), p. 617-640.

Yoder, H.S. and Tilley, C.E., 1962. Origin of basalt magmas: an experimental study of natural and synthetic rock systems: J. Petrol., v. 3, p. 342-352. 